\title{
Empowering the Small and Medium Enterprises in Bangladesh: Lessons from China
}

\author{
Md. Rabiul Islam Rabi, S M Salim Reza, S M Sazid Raihan
}

\begin{abstract}
To achieve a double digit growth, Bangladesh requires the right mix of human capital, policy and supportive bureaucratic structures to encourage entrepreneurship. Bangladesh must learn not only to develop and find global markets for its own industrial production, but look for it abroad and bring ideas back to be commoditized at home. The purpose of this article is to extract policy lessons from the SME development of China in the perspective of Bangladesh. The paper draws policy prescriptions to boost entrepreneurship through research, innovation, tax reform, market reform, education and training.
\end{abstract}

Keywords - SME, human Capital, entrepreneurship, Tax Reforms, employment generation, innovation.

\section{Introduction}

Human talent is often trapped by Bureaucratic restrictions. We must devise our policies to arrest the benefit of human talent in more entrepreneurial ways. The papers aims to focus on the pressing challenges faced by the SME sector of Bangladesh.

The paper is organized as follows: It begins with an overview of the key characteristics and composition of SME sector of Bangladesh. The paper then provides the rationale for using Chinese SME Development in devising appropriate policies. It then provides policy recommendation drawing from the Chinese SME Development strategies in the context of Bangladesh.

\section{Objective of the Study}

The objective of the study is to address the question "What lessons can we take from Chinese SME development for that of Bangladesh?"

Md. Rabiul Islam Rabi

Research Associate(Academic Wing), Lead to Live Foundation Dhaka, Bangladesh

S M Salim Reza

Assistant Professor, Dept of ICT

Bangladesh University of Professionals (BUP),

Dhaka, Bangladesh

\section{Methodology of the study}

The paper is exploratory in nature. The paper uses secondary data from various archives of government documents, journals, publications and related statistics.

\section{Definition of SME}

The definition of SME varies from country to country. This paper takes the definition put forward by National Industrial Policy 2010 into consideration. Any firm employing more than 10 but less than workers is considered as Micro-Enterprise. On the other hand, if the number of employees remains between 25 to 99 , the enterprise is regarded as Small. A medium enterprise is defined as the one which employs 100 to 249 workers in Bangladesh [1].

\section{v. Current Status of SMEs in Bangladesh}

According to Bangladesh Bureau of Statistics, SME is a substantial component of the manufacturing sector (with 10 or more worker) in Bangladesh comprising of $35.5 \%$ of employment, $50.9 \%$ of the establishments, and $47 \%$ of gross value added.[2] Bakht and Basher (2015) argues that "SMEs have been the more dynamic component of the manufacturing sector during 2005/06-2010/11 and accounted for about 4.5 percent of total employment (i.e. 35.5 percent of total manufacturing employment) and 12.4 percent of GDP (i.e. 69.9 percent of total manufacturing value-addition) in FY11. However, the demonstrated dynamism conceals two important factors. First, the heterogeneity of the sector; available research shows that there are significant inter-industry variations in productivity growth within the sector. While some are growing by taking advantage of the liberalized trade regime, some are struggling to thrive in the growing competition. Secondly, despite the demonstrated dynamism during 2005/06-2010/11 the SME sector is facing a number of constraints, which need to be taken care of. Some of these constraints are generic in the sense that they are common to the manufacturing sector while some are specific to the SME." [3]

\section{vi. Government's support structure for SME}

Government of Bangladesh has taken multiple initiatives to support the SME sector. In 2004, National Task Force on 
SME was formed. A document for policy strategies was for SME in 2007. In order to render institutional support for SME as suggested by the National Task force, SME Foundation was established in 2007. SME Foundation is now working dedicatedly along with SME cell of industry ministry to provide promote SME sector. With the advent of SME foundation the, Ministry of Industry, Bangladesh Small and Cottage Industries Corporation (BSCIC) and SME foundation is now making concerted effort to bolster the SME sector through a multi-institutional approach. Though its inception was in 2007, SME Foundation is yet to make remarkable progress in promoting $\mathrm{SME}^{1}$.

\section{vII. Lessons from Chinese SME experience}

The Small and Medium Enterprises, in other words "Township and Village Enterprises" (TVEs) in the context of China, has shown stellar performance in boosting Chinese economy. China. China's performance in reducing poverty has intrigued the researchers on understanding the mechanics of growth. The remarkable ascent of China as a global economic superpower has been fuelled by multiple factors. Economic reform complemented by broad changes in Chinese politics and legal framework expedited the growth.

Though a large number of people is still mired in poverty, China's performance in poverty reduction since 1978 has been outstanding. Yasheng Huang makes a compelling argument that, "the economic growth of China in late 1970 's and its poverty reduction for the next couple of decades was a function of rural developments in general." (Huang, 2012) The rural industry, spearheaded by the upswing of township and village enterprises, has contributed to China's take off as an economy. Huang (Huang, 2012) also argues that, " Rural private entrepreneurship and financial reforms correlate strongly with some of China's best known achievements- poverty reduction, fast GDP growth driven by consumption (rather than by Corporate Investments and government spending), and an initial decline of inequality"[4]

Along with China's reform and opening-up, China's SME's development phase can be characterized in three stages. In 1978, China's initial rural reform propelled the economic growth instantaneously. Between 1978 and 1984, rural per capita income more than doubled and rural per capita consumption registered a 51 percent increment. Within the first decade of reform China experienced a sharp decline in rural poverty [5].

\section{A. Industry information database}

The first lesson, we can take from China, is identifying the underdeveloped rural regions and the regional demand for goods and services to explore market opportunities.

${ }^{1}$ A Strength, Weakness, Opportunities, Threat (SWOT) analysis can be found on Bakht and Basher (2015)
Identification of regional demand for goods and services will help create required policy support for the specific area. Bangladesh is already working on cluster development for SME which has gained much prominence lately in different countries like China, France, USA.

An essential element of development strategy to boost the SME sector is collect and analyze the relevant industry related information. A comprehensive database will enable the SME Foundation to devise and implement policies in efficiently. Bangladesh lacks such digitized databased both from the perspective of consumers and providers. SME foundation can mobilize its resources along with the help of relevant ministry to prepare a comprehensive database for region-specific information.

\section{B. Taxation Policies}

Bangladesh can learn from the preferential taxation polices of China. Like China, the government can design a differentiated tax rate for SME to reduce the tax burden from SME. Government can also reduce the Value added tax (VAT) for small enterprises depending on the annual sales revenue. Such measures require the government to have a clear trace of the annuals sales revenue which will not be easy at first.

- Taxation policies to promote unemployed: China promoted employment through taxation policies. Chen (2006) states that, "If a new urban job agency in its first year of operation is able to find jobs for urban residents, of which more than 60 per cent are unemployed workers, the agency is eligible for exemption from business income tax for three years; after the exemption period expires, if the agency is able to find jobs for unemployed workers that exceed 30 per cent of its total jobs found, then it gets 50 percent discount on the enterprise income taxes for two years. "[6]

- Preferential taxation policies: Government can also design preferential taxation policies for enterprises in poor and underdeveloped areas. This will require the government to officially identify poor and underdeveloped areas.

- Taxation to promote welfare enterprises: To promote employment opportunities for disabled people, the government of Bangladesh can also follow by granting preferential taxation policies to welfare enterprises attached to such people.

- Taxation policies for high-tech enterprises: Through taxation policies, China promotes high-tech enterprises which are located in the state-level high tech industry development zones. Such high tech enterprises are exempted from enterprise income tax for two years from the year they go into operation. After two year, the enterprises enjoy a preferential income tax rate of 15 per cent.[6] 


\section{Fiscal Policies}

China government promoted SME industry by taking various fiscal policies. Especially in 1990's, several fiscal funds were set up with SMEs' as targeted beneficiaries. Innovation Fund for Technology based SMEs, Commercialization Fund for Agricultural Research Findings, Fund for International Market Exploitation by SMEs etc. are praiseworthy initiatives taken by the Ministry of Finance of China to promote SME sector [6].

SME foundation of Bangladesh needs such support to boost the SME development. Ministry of Industry and Ministry of Commerce and other concerned authorities can work on a detailed plan to imitate such policies to support the SME sector. SME foundation cannot work independently until it gets the necessary budgetary allocation from the government. Furthermore, resource mobilization is will be a daunting challenge too for the Bangladesh.

\section{Capacity Building}

Over the time, former State Economic and Trade Commission (SETC) took various steps to bolster the SME industry. From credit guarantee scheme to SME financing, training and development, SETC issued several "Opinion Papers" to elevate the status of SME across the society (Chen, 2006). SME foundation of Bangladesh is already imparting training on various arenas. Capacity building and human resource development must be focused as vehicle to boost the SME sector. Different training programs should be designed on various aspect of an entrepreneurs like business plan writing, account management, tax management, quality supervision etc.

\section{E. Technology Innovation}

The present government of Bangladesh has created a buzzword named "Digital Bangladesh" in its election manifesto. The government is already embracing the digital revolution around the globe and trying to implement it in public affairs widely. Bangladesh has a lot to learn from the China when it comes to science and technology innovation. By the end of 2003, China took a handful of supportive measure to boost the SME sector. (Chen, 2006) China's bold steps to establish over 10 service centers for SMEs' and more than 500 productivity promotion centers have provided institutional support for the technological innovations of SMEs'. (Xiwei, 2007)

\section{vIII. Conclusion}

Schumpeter (1934) in "The Theory of Economic Development" underscores the role of entrepreneur as a prime factor for economic development. Schumpeter (1934) also stressed this development to be achieved through innovation. As Bangladesh marches forward to step into the middle income block, it must look for productive employment opportunities for its growing pool of labor force. Government has to adopt appropriately targeted policy based on the nature of SMEs. "One size fits for all" policy might not work well in case of SME.

Besides, a conducive investment climate is a prerequisite to foster the SMEs. In accordance with legal and regulatory framework and appropriate macroeconomic policies, quality governance must be ensured to set the ground for an investment friendly environment.

Evidence shows that, without government support Chinese SME development would not have experienced such growth [6]. The dominant reason for the accelerated growth of Chinese SMEs' is considered as 'they adapt themselves to the requirements of the market economy and adjust their development strategy and industrial structure to formulate a healthy mechanism of self-governance, self-determination and self-development, thus boosting their development initiative and dynamism. "'[6]

Bangladesh can have a similar wave of positive transitions in the SME sector if lessons are drawn from the Chinese SME experience. A precaution must be taken while drawing such lessons that is the country experienced different political economy than Bangladesh. As a result, Bangladesh should set foot for the policies which commensurate with its political economy.

\section{References}

[1] Ministry of Industries. (2010). National Industrial Policy . Dhaka : Ministry of Industries.

[2] BBS (2010) Report on Bangladesh Survey of Manufacturing Industries (SMI) 2005-2006

[3] Bakht, Z., \& Basher, A. (2015, March 31). Planning Comission, Ministry of Bangladesh. Retrieved from Planning Comission Website: http://www.plancomm.gov.bd/7th-five-year-plan/

[4] Huang, Y. (2012). How did China Take Off . Journal of Economic Perspectives, 147-170.

[5] Riskin, C. (1987). China's Political Economy. New York: Oxford University Press.

[6] Chen, J. (2006). Development of Chinese small and medium-sized enterprises. Journal of Small Business and Enterprise Development 13.2, 140-147.

[7] Xiwei, Z. \&. (2007). Science and technology policy reform and its impact on China's national innovation system. Technology in Society, 317-325.

[8] Shumpeter Joseph, (1934) The Theory of Economic Development.Cambridge: Harvard University Press 
Proc. of The Fourth Intl. Conf. On Advances in Economics, Management and Social Study - EMS 2015

Copyright (C) Institute of Research Engineers and Doctors, USA .All rights reserved.

ISBN: 978-1-63248-071-2 doi: 10.15224/ 978-1-63248-071-2-26

About Author (s):

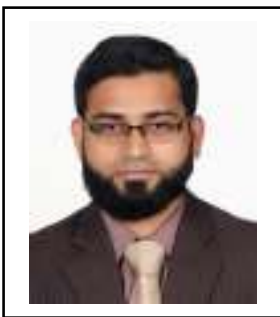

Md. Rabiul Islam Rabi has completed his Masters and Bachelors in Social Science in Economics from Department of Economics, University of Dhaka. His research interest focuses on human capital, economic growth, labor economics and moral philosophy.

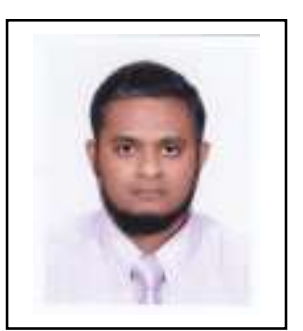

S M Salim Reza has been serving as Assistant Professor of the Department of ICT, Faculty of Science and Technology (FST) in Bangladesh University in Professionals, Mirpur Cantonment, Dhaka, Bangladesh

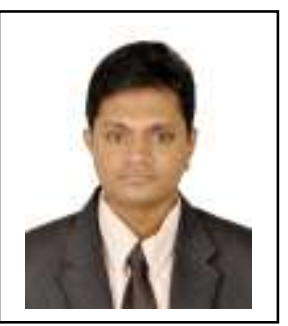

S M Sazid Raihan is currently pursuing his Masters in Business Administration, with a major in Human Resources Management, in North South University. He has obtained his Bachelors in Business Administration from North South University. His research interests are human resource management, entrepreneurship and Organizational management. 